\title{
CHINESE COMPANIES, EARNINGS MANAGEMENT AND ACCOUNTING-BASED BENCHMARKS
}

\author{
Pei Yang \\ Department of Accounting, Finance and Information Systems, University College Cork \\ and \\ Mark Mulcahy \\ Department of Accounting, Finance and Information Systems, University College Cork
}

\begin{abstract}
$\mathrm{T}$ his paper studies whether Chinese-listed firms manage earnings to meet accounting-based regulatory benchmarks. The distribution approach is employed to test the hypotheses that listed Chinese companies' managed earnings to avoid being delisted and to satisfy the requirements of rights issues. The findings indicate that earnings management behaviour by Chinese firms changes in line with changing regulatory benchmarks, and firms utilise accruals rather than the manipulation of real economic events to do so. The findings in this paper suggest that regulatory authorities should pay close attention to the framework of the regulatory rules they establish.
\end{abstract}

\section{INTRODUCTION}

Financial statements report how a company performed financially in the previous operating period and often explains the scope of its business mission and management philosophy. As such, they are very important documents and are often the first documents an investor consults when researching a company. However, there are two contradictory imperatives - being precise and being clear. In order to enhance the relevance and reliability of financial reporting and make things easier to understand for the investor, financial statements need to be prepared in accordance with generally accepted accounting principles that assume unbiasedness on 
part of managers, and generally grant substantial flexibility to allow firms to selectively use their discretion in conveying firm-performance to outsiders.

Earnings management involves management's intentional and opportunistic manipulation of financial reports for personal gain. So, while corporate managers can use discretion to report earnings that accurately reflect the firm's underlying economic situation, the leeway to exercise judgement allowed by accounting rules may also be abused for earnings management by corporate insiders when it is in their interest (i.e. to hide poor economic performance or to achieve an earnings target). Thus, managers are posited to opportunistically manage earnings to maximise their own utility at the expense of other stakeholders.

Earnings management has become an issue of critical importance in today's capital markets. Corporate reporting scandals (such as Enron, Worldcom, Xerox) have raised serious concerns regarding the credibility of this performance measure among financial markets' regulators, operators, investors and academic researchers in many countries. Not surprisingly, it is also a serious problem in China where the institutional setting is still incomplete relative to that of western countries. Indeed, Chinese firms have additional incentives to manage earnings to meet benchmarks that determine whether or not they can raise additional capital via new rights issues (in a market where alternative sources of capital are limited) and whether or not the firms can stay listed on the stock exchange. In contrast, the cost of earnings management is expected to be relatively low because the users of accounting information in China (including regulators) are less sophisticated.

Most of the previous studies on Chinese firms have focused on accrual-based earnings management relating to specific corporate events when the companies would have strong motivation to manage earnings. The distribution method that relies on pooled cross-sectional distributions of reported earnings levels has been used to test for earnings management on firm samples in mature and developed economies (Burgstahler and Dichev, 1997; Degeorge, Patel and Zeckhauser, 1999; Holland and Ramsay, 2003). This study examines the Chinese stock market with its different regulatory policies and institutional setting. Yu, Du and Sun (2006) used a modified distribution approach on a sample of Chinese companies but restricted their focus to a single regulatory-imposed benchmark (return on equity) and only supplied a cursory test as to the method by which earnings are managed by Chinese firms to meet this benchmark. This study employs the distribution method to a broader set of regulatory-induced accounting-based benchmarks to test for the pervasiveness of earnings management in response to securities regulations relating to delisting and/or the requirements of rights issues. In that regard, our study is a comprehensive analysis of earnings management to meet/exceed benchmarks in China that also includes a robust analysis of the method used to manage those earnings.

\section{LITERATURE REVIEW}

Since Hayn (1995), many international studies examining the prevalence of earnings management in order to avoid reporting losses and/or earnings decreases have 
adopted a distribution approach to test for the behaviour of earnings management (see Degeorge et al., 1999; Holland and Ramsay, 2003; Dechow, Richardson and Tuna, 2003; Ayers, Jiang and Yeung, 2006; Ronen and Yaari, 2010). This approach relies exclusively on the distribution of reported earnings around these points rather than on estimating the abnormal or discretionary components of total accruals (i.e. Healy, 1985; Jones, 1991; Dechow, Sloan and Sweeney, 1995; McNichols, 2000) and is therefore considered a more objective method with which to detect earnings management.

Burstahler and Dichev (1997) find that there are unusually low frequencies of small decreases in earnings and small losses and unusually high frequencies of small increases in earnings and small positive income. Degeorge et al. (1999) conclude that earnings management is driven by three thresholds: to report positive profits, to sustain recent performance (at least last year's earnings), and to meet analysts' expectations (particularly the analysts' consensus earnings forecast); Holland and Ramsay (2003) find similar evidence in Australia. Ayers et al. (2006) find that forward-looking discretionary accruals are higher for firms just above the lossavoidance benchmark than for firms just below. However, using an alternative test period, Dechow et al. (2003) test the same relationship but do not find any significant difference. Hansen (2010) finds that the lack of evidence in Dechow et al. (2003) is due to the impact of alternative benchmark goals (earnings improvement and/ or analyst forecast) and finds that after controlling for the alternative benchmarks, firms with small profits have significantly higher abnormal accruals. A number of other studies provide both direct and indirect evidence that managers engage in income-increasing behaviour to meet benchmarks (Bhattacharya, Black, Christensen and Larson, 2003; Ayers et al., 2006; Beaver, McNichols and Nelson, 2007; Dechow et al., 2003; Durtschi and Easton, 2005).

Leuz, Nanda and Wysocki (2003) find that the countries where earnings management was most prevalent were also the ones with the weakest enforcement regimes and the lowest influence exerted by outside investors, while those countries that did the best have not only strong enforcement mechanisms but also outsider economies, in which firms rely heavily on the stock market and other investment channels to raise capital. In line with this, previous empirical evidence from China indicates that managers of listed firms have strong incentives to manage earnings to meet benchmarks. For example, Aharony, Lee and Wong (2000) and Kao, Wu and Yang (2009) find earnings management among Chinese firms sold to foreign investors prior to their initial public offerings (IPO-packing). Chen, Jian and Xu (2009) explain that this may be due to tunnelling where proceeds from the IPO are diverted to controlling shareholders via dividends. Yu et al. (2006) use a modified distribution approach to examine earnings management at exogenously determined ROE thresholds that China's listed firms must exceed for the approval of rights issues. They find evidence that firms manage their earnings to meet the requirements for rights issues and changed their behaviour as the benchmark changed. Jiang and Wei (1998) find an increasing percentage of firms reporting an ROE in excess of 10 per cent (the minimum China Securities Regulatory Commission (CSRC) threshold for raising further rights issues at the time. The CSRC is the Chinese equivalent to the US Securities and Exchange Commission). Chen and Schoderbek (1999) show that 
those firms reporting an ROE slightly above the 10 per cent threshold also reported unusual movements in accounts receivable days.

Jiang (1999) finds that when listed companies expect either that earnings will be less than zero or that ROE will be less than 10 per cent, they attempt to manipulate profits to report earnings above break-even or to get ROE once again above the critical qualification point for rights issues. Similarly, Chen and Yuan (2004), Haw, Qi, Wu and $\mathrm{Wu}(2005)$ and $\mathrm{Yu}$ et al. (2006) demonstrate that these firms (reporting ROEs slightly higher than the relevant threshold) execute transactions involving below-the-line items and use income-increasing accounting accruals to meet regulatory ROE targets for stock-rights offerings. Because shares sold in rights issues are non-tradable, Huang, Shen and Sun (2011) find that existing controlling shareholders tend not to participate. Huang et al. hypothesise that such shareholders are motivated to manage earnings upward in order to raise more capital for the firm. $\mathrm{Lu}$ (1999) also finds evidence of earnings management among companies at risk of being delisted. He observes that if companies report a loss in any year, they increase the size of the loss in the first year of losses and reverse this if/when they become profitable. Sun and Wang (1999) found that the motivation to manage earnings is related to the government regulations, especially the policies of special treatment, rights issues and delisting. Thus, there exists strong managerial incentive to, inter alia, avoid being delisted from stock exchanges and to raise more capital subsequent to IPO that stems from the institutional background in China.

\section{INSTITUTIONAL BACKGROUND IN CHINA}

During the early 1990s, the Chinese government established two stock exchanges in Shanghai (November, 1990) and Shenzhen (April, 1991). Prior to this, most Chinese companies were state-owned and poorly performing - a third of firms reported persistent explicit losses, another third reported implicit losses, and only a small portion reported profits. Without the state's subsidies, the majority of these enterprises would have immediately collapsed. One of the aims of the reforms that led to the establishment of the Shanghai and Shenzhen stock exchanges was to facilitate the injection of new equity capital into the SOEs that would relieve the financial burden on the government and make SOEs more prudent in their use of capital. In the absence of other attractive investment opportunities, Chinese companies benefited greatly from the resulting rapid growth in equity issuance to individual investors. By the end of 2004, there were 1,373 public companies listed on the two exchanges, with a total stock-market value of over CN¥3,705.56 billion (US\$448 billion).

The availability of equity capital is extremely important for Chinese companies because, unlike more developed economies, the banking sector in China is neither well developed nor efficient, which limits the availability of external financing options. As a result, and due to the flexibility and relatively low cost of equity financing, the demand for a stock-market listing among Chinese companies is very high. However, due to the immaturity and volatility of the Chinese stock market, the government sets listing standards including imposing a quota system (which 
started to be phased out in 1999 and was replaced by the 'verification' or 'examination' system in 2001) to regulate the listing of firms in the market. As a result, a large and growing number of firms are waiting to be listed on the stock exchanges of which only a small portion receive government approval each year. Thus, the listing qualification is a scarce resource for companies in China and is viewed as a significant asset for any company.

Before the CSRC will allow any company to issue additional shares to existing shareholders, they require listed companies to meet certain return on equity (ROE) benchmarks. The standard for listed firms to issue rights has been set and reset a number of times to keep pace with the rapid development of the capital markets. From 1996 to 1998, the minimum ROE threshold to issue stock rights was set at 10 per cent in each of the three previous years. This was lowered to 6 per cent each year with an average rate of above 10 per cent on the three most recent years from 1999 to 2000. From 2001 onwards, the criterion was modified so that three-year average ROE must be greater than 6 per cent and the expected ROE for the year-of-rights issue should also be greater than 6 per cent. In a similar vein, in order to protect minority shareholders and to encourage better corporate governance, the CSRC has issued a number of rules regulating listed firms, including a special delisting mechanism introduced in 1998. Under the guidelines of this mechanism, the stock exchanges will first label a firm with losses of two consecutive years as a 'special treatment' firm, then designate it as a 'particular transfer' (PT) firm if it fails to turn profitable within one year. However, from 2002 onwards, the PT mechanism was abolished. Instead, a listed firm will be suspended if it has negative net profits for three consecutive years, and will be delisted if it cannot satisfy the corresponding requirement for staying listed during the grace period. So, for controlling shareholders and other insiders, becoming a PT firm - or worse, actually being delisted - would lead to the loss of private control benefits and future rent-seeking opportunities.

All these rigid regulations based on accounting numbers provide managers at Chinese firms with strong additional incentives to manage earnings to meet (i) the zero benchmark in order to avoid a process that could ultimately lead to the firm being de-listed from the stock exchange, and (ii) the ROE benchmark to be allowed to raise new equity capital from existing shareholders.

\section{DATA AND METHODOLOGY}

Although the original aim of the listing and rights issue regulations in China (zero-loss and targeted ROE benchmarks) was to maintain the equilibrium of the capital market and to foster rational investment environment, their accountingbased nature is likely to induce pervasive earnings management. The two critical regulatory thresholds that the managers in Chinese listed firms feel compelled to meet are zero, and the ROE requirements for rights issues. Although not mandated by the Chinese regulatory authorities, per Degeorge et al. (1999) and Holland and Ramsay (2003), we also include last period's earnings as an additional test that is linked to the zero threshold (i.e. beating the previous year's profits necessarily means that losses are avoided). The hypotheses, stated in positive form, are: 
Yang and Mulcahy

Hypothesis 1 (H1): Earnings are managed to report positive profits.

Hypothesis 2 (H2): Earnings are managed to sustain the previous year's profit performance.

Hypothesis 3 (H3): Earnings are managed to beat the ROE requirement for rights issues (depending on which year's data is used.)

As mentioned previously, the regulatory requirements for rights issuing has changed several times, resulting in a regulatory ROE threshold of 10 per cent 19982000, and from 6 per cent from 2001 onwards. Thus, the whole sample is divided into two sub-samples of 1998-2000, and 2001-2004 when testing H3.

The manipulation of cash flows from operations also permits earnings to be moved from below a specific threshold to above it. Indeed, Burgstahler and Dichev (1997) found that both cash flow from operations and changes in working capital have been used to manage earnings around thresholds. For this reason, besides investigating the earnings at thresholds, we also investigate the pooled, cross-sectional distribution of reported operating cash flows for discontinuities at the same thresholds to divine how Chinese companies are managing earnings.

Kim, Liu and Rhee (2003) investigate the relation between corporate earnings management and firm-size, and find that firm-size plays differing roles in earnings management. Their results show that small-sized firms engage in more earnings management to avoid reporting losses than large or medium-sized firms. However, the latter exhibit more aggressive earnings management to avoid reporting earnings decreases than the former. For this reason, the whole sample is split into large and small-size firms to investigate whether firm-size plays a role in the management of or earnings by Chinese listed firms. In the empirical tests, firm-size is measured using a firm's total assets at the fiscal year-end. The group of firms whose total assets are above each year's median are regarded as 'large' firms and those below are labelled 'small' firms.

As implemented by Burgstahler and Dichev (1997), the distribution approach assumes that the cross-sectional distributions of earnings levels and earnings changes are relatively smooth in the absence of earnings management. Therefore, the shape of the distribution histograms should closely resemble the theoretical properties of the normal distribution. When earnings management exists, the number of observations of scaled earnings (levels or changes) will be underrepresented in 'unfavourable' intervals of the distribution and overrepresented in 'favourable' intervals. If managers are engaging in earnings management in response to thresholds, distributions will get distorted around these thresholds - we would expect to observe unusually few observations just below the threshold and unusually many observations just above the threshold. In addition to observing the discontinuity of earning and changes in earnings around thresholds to be tested, this study also computes a test statistic to indicate whether or not to reject the null hypothesis that the distribution underlying the histogram is continuous and smooth at the earnings threshold. The test statistic used is the difference between the actual and the expected number of observations in an interval, divided by the estimated standard 
deviation of the difference (under the null hypothesis, these standardised differences will have an approximately normal distribution, with mean 0 and standard deviation 1):

$$
\tau=\frac{n_{a}-n_{e}}{\sigma}
$$

where $\tau=$ test statistic approximately distributed under a normal distribution, $n_{a}=$ actual number of observations in the interval, $n_{e}=$ expected number of observations in the interval, and $\sigma=$ standard deviation of the difference. The estimated standard deviation of the difference is calculated as:

$$
\sigma=\sqrt{N p_{i}\left(1-p_{i}\right)+\frac{1}{4} N\left(p_{i-1}+p_{i+1}\right)\left(1-p_{i-1}-p_{i+1}\right)}
$$

where $p_{i}=$ fraction of observations in the $i$-th interval, and $N=$ total number of observations. ${ }^{1}$

The sample used to test the hypotheses in this study includes the entire population of A-shares of listed Chinese firms on the Shenzhen and Shanghai stock exchanges for 1998-2004. For each sample year, the annual financial statements of the sample firms are obtained from the CSMAR database where the financial year-end is between 1 January 1998 and 31 December 2004. The sample begins in 1998 because this study also analyses cash flows and the cash-flow statement was only required by the CSRC since 1998. Lagged total assets are used for scaling purposes. Banks and financial institutions are excluded from the sample. The initial public offering (IPO) firms are also excluded because the focus of this research is on the normal listed firms during their normal operating period, and the motivation for earnings management by IPO firms is likely to be different from regulation-related incentives studied in this paper. Furthermore, when testing H3, the listed firms whose net assets are less than zero are also excluded from the sample (if the net assets are less than zero, the calculation of the ROE is meaningless). Finally, any firms lacking the necessary data are also excluded from the sample. The initial sample obtained is 7,727 firm-years and after excluding companies as outlined above, 7,104 firm-years of data remain to test $\mathrm{H} 1$ and $\mathrm{H} 2$, and 6,963 firm-years of data remain for testing $\mathrm{H} 3$. Consistent with the previous literature, all data are winsorised at the $1 \%$ level to avoid the influence of outliers.

\section{RESULTS}

Figure 1 shows the distribution of net income after tax with histogram interval widths of 0.005 ranging from -0.25 to +0.25 . If earnings are managed to meet the zero threshold, we expect to find a concentrated number of observations in the first positive interval and a discontinuity at the zero threshold. An initial inspection of the histogram shows that there is a significant asymmetry in the distribution with fewer observations falling into the left side of the zero threshold than the right side. Specifically, in the interval just immediately left to zero [-0.005, 0], there are only 
9 observations, in contrast with the interval just immediately right to zero [0, 0.005], with 484 observations. These visual results are strongly supported by the test statistic - the standardised difference for the interval immediately above zero is 11.06 and the standardised difference for the interval immediately below zero is -21.58. Assuming that the standard differences are approximately normal, this would lead to a rejection (at better than the $1 \%$ level) of the null hypothesis that the distribution is relatively smooth, and acceptance of the alternative hypothesis that there is a discontinuity at zero in the distribution.

\section{FIGURE I: DISTRIBUTION OF NET INCOME AFTER TAX}

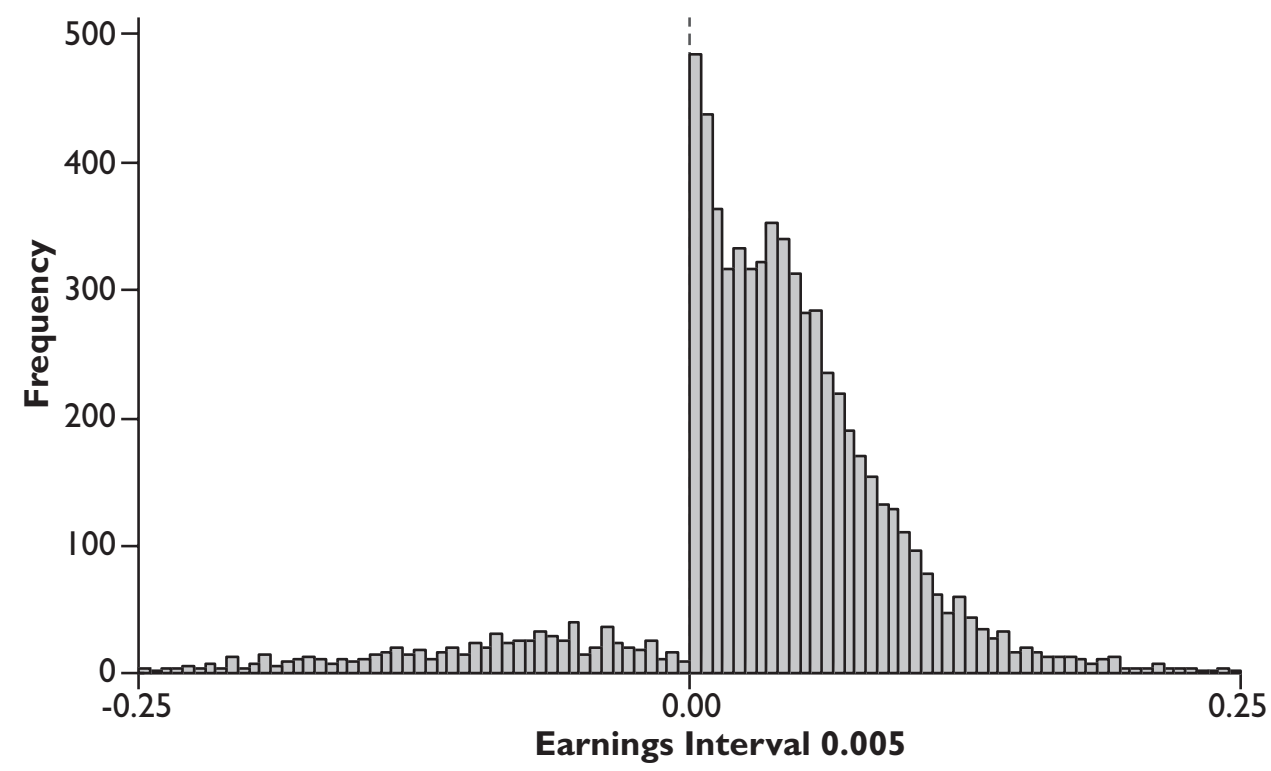

The distribution of annual net income after tax (CSMAR item \# BI50I0I) scaled by beginning-of-the-year total assets (CSMAR item \#A100000). Dotted line marks the location of zero on the horizontal axis.

To test whether the results are robust to differences in firm-size, all of the observations are divided at the median, based on firm-size. The descriptive statistics for scaled net income after tax, and changes in scaled net income after tax as well as ROE in the two size groups, are summarised in Table 1 . The standardised difference of the interval right of zero among larger firms is 9.10 (-15.96 for the interval left of zero), and among smaller firms is 6.46 (-14.54 for the interval left of zero). Thus, although larger firms are, on average, more profitable than smaller firms (per the results of a difference in means test included at the bottom of Table 1), the tendency to manage earnings to meet the zero-earnings benchmarks is similar for both groups such that this study can accept $\mathrm{H} 1$.

$\mathrm{H} 2$ proposes that earnings are managed to sustain the previous year's profit performance. The pooled cross-sectional distribution of changes in net income after tax are included in Figure 2. With histogram interval widths of 0.0025 for scaled earnings ranging from -0.15 to +0.15 , the histogram shows a single-peaked, bell-shaped 
TABLE I: DESCRIPTIVE STATISTICS

Net Income after Tax

\begin{tabular}{lccccccc}
\hline & $\mathbf{N}$ & Mean* $^{*}$ & Std. Dev. & $\mathbf{2 5 \%}$ & $\mathbf{5 0 \%}$ & $\mathbf{7 5 \%}$ & \% Positive \\
\hline Large & 3484 & 0.0340 & 0.0610 & 0.0113 & 0.0358 & 0.0636 & $90.27 \%$ \\
Small & 3484 & 0.0279 & 0.0790 & 0.0083 & 0.0364 & 0.0677 & $85.91 \%$ \\
\hline
\end{tabular}

*t test for differences in means $\mathrm{t}=\mathbf{3 . 6 4}$ significant at 0.000

This table reports the distribution of earnings for sample firms categorized by company size. Companies are classified into large and small based on sample median total assets.

distribution that is relatively smooth except in the area of zero-earnings changes. The test statistics of 6.42 and -5.35 above and below zero, respectively, are both significant at better than the $1 \%$ level and are consistent with earnings management to avoid earnings decreases (i.e. earnings changes slightly less than zero occur less frequently than would be expected given the smoothness of the remainder of the distribution, and earnings changes slightly greater than zero occur more frequently than would be expected), such that this study can accept H2. The results (not reported here) are also robust to firm-size.

FIGURE 2: DISTRIBUTION OF CHANGE IN NET INCOME AFTER TAX

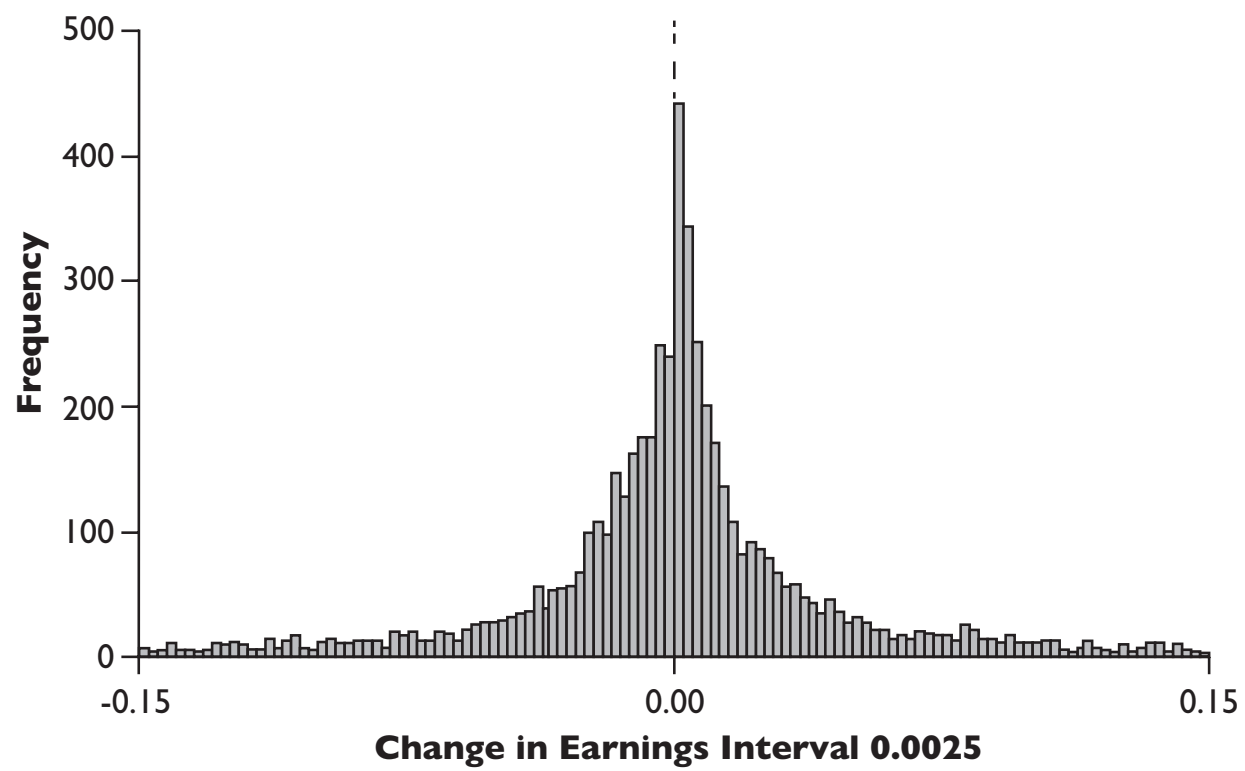

The distribution of changes in annual net income after tax (CSMAR item \# BI50I0I) scaled by total assets (CSMAR item \#AI00000) as of the beginning of the first year. The dotted line marks the location of zero on the horizontal axis.

$\mathrm{H} 3$, concerning ROE thresholds, is investigated by splitting the total sample into two sub-samples of years, 1998-2000 and 2001-2004. For the sub-sample 19982000, the applicable three-year average regulatory ROE benchmark is 10 per cent. A histogram of the sample of the 2,386 observations from 1998 to 2000 (Panel A of 
FIGURE 3: DISTRIBUTION OF ROE
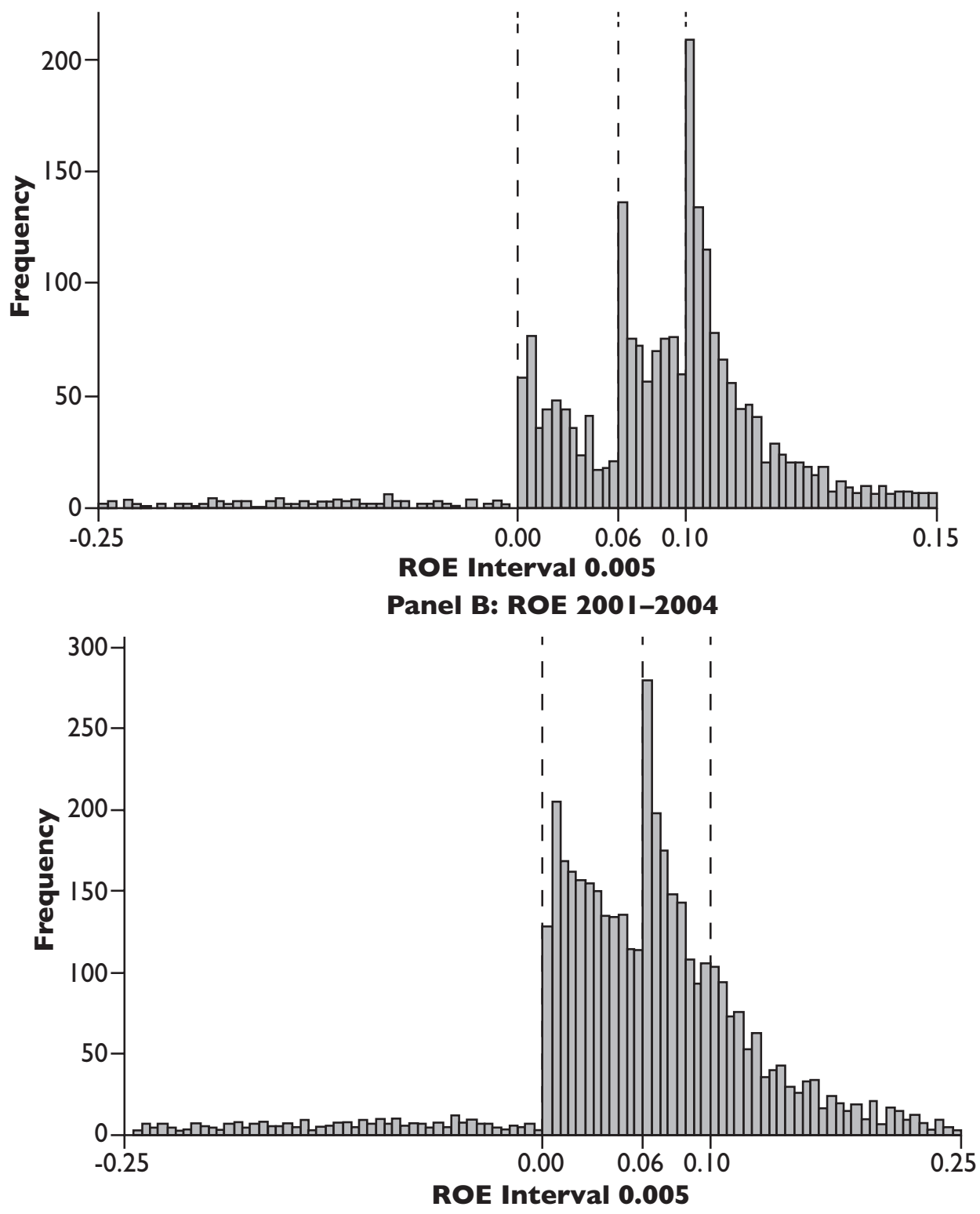

The distribution of ROE which is calculated by annual net income after tax (CSMAR item \#BI50IOI) scaled by fiscal-year-endbook value of equity (CSMAR item \#A300000). Dotted lines mark the location of the zero, six and ten per cent thresholds zero on the horizontal axis.

Figure 3) is plotted with an interval of 0.005 ranging from -0.25 to +0.25 . As documented by earlier studies, it is apparent that there is an out-of-proportion clustering of companies in the ROE interval $(0.100,0.105)$ and a discontinuity at the 10 per cent 
threshold. The test statistics confirm the results with 7.24 above and -7.45 below the 10 per cent threshold.

It is also be observed that there are two additional significant discontinuities at the 6 per cent and zero thresholds - the test statistics are 7.15 above the 6 per cent threshold (-7.42 below) and 2.24 above zero (-7.84 below). The discontinuity at the

FIGURE 4: DISTRIBUTION OF CASH FLOWS

Panel A: Scaled Cash Flows
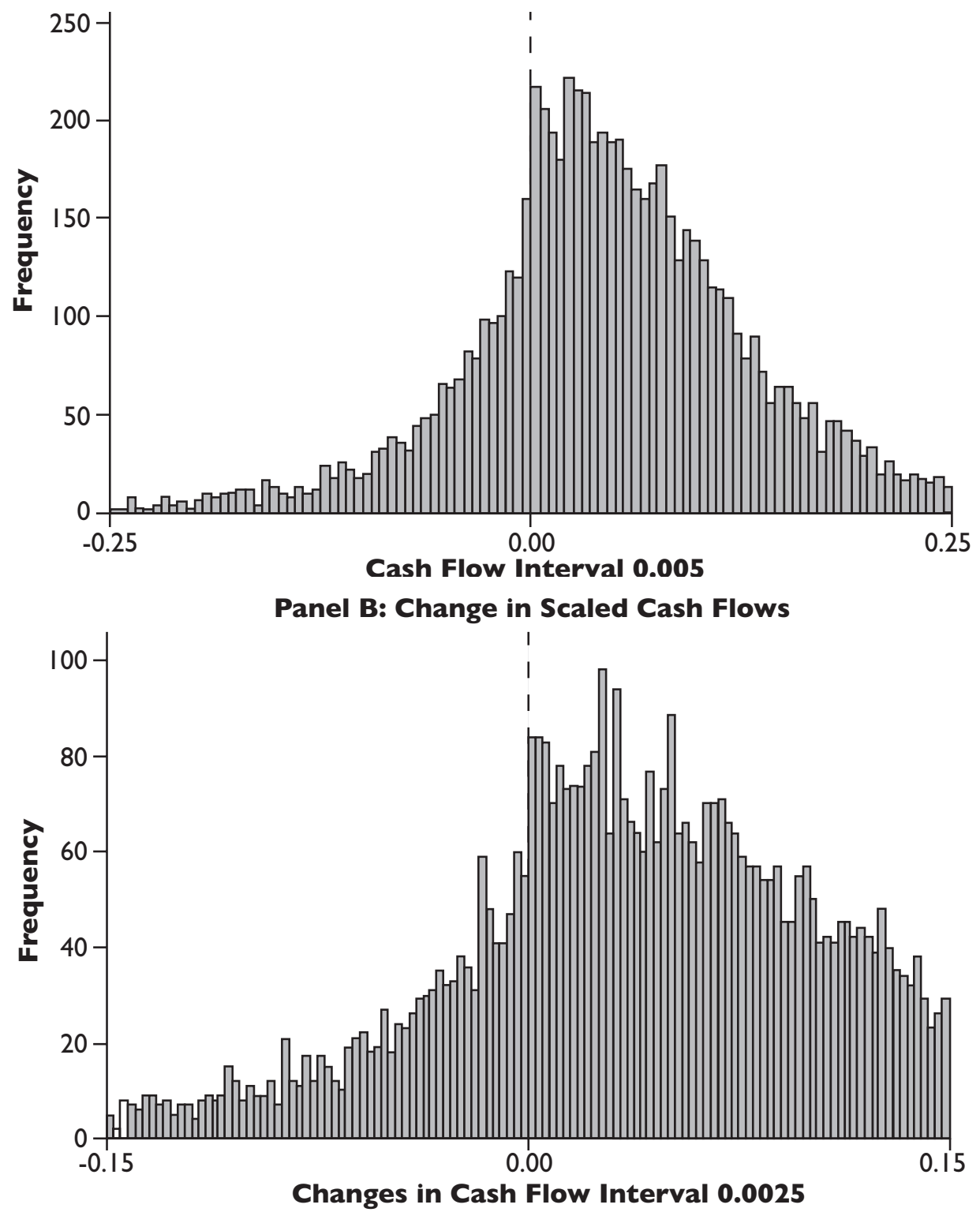

The distribution of annual operating cash flows (CSMAR item \#DI00000) scaled by beginning of the year total assets (CSMAR item \#AI00000).Dotted line marks the location of zero on the horizontal axis. 
6 per cent threshold is consistent with the securities regulation in place at the time that in each of the previous three years, the ROE must be greater than $6 \%$ with an average ROE greater than 10 per cent for a firm to qualify for a rights issue.

For the sub-sample 2001-2004, the applicable three-year average regulatory ROE benchmark is 6 per cent. Panel B of Figure 3 displays the histogram of the sub-sample of the 4,441 firms where it is evident, confirmed by the test statistic, that there are salient discontinuities at the 6 per cent threshold as well as the zero threshold. However, the significant discontinuity evident for the sub-period 1998-2000 is no longer present.

The results from both sub-periods provide strong evidence of earnings management to meet the average 10 per cent and 6 per cent ROE regulatory criterion for rights issues for the 1998-2000 and 2001-2004 periods, respectively, as well as some evidence of earnings management to meet the 6 per cent ROE minimum criterion for the 1998-2000 sub-period. Therefore this study can accept H3. The discontinuity at the zero threshold also provides additional support for $\mathrm{H} 1$, that the listed firms manage earnings to report positive profits. The results for each sub-sample (not reported here) are also robust to firm-size.

As documented in previous literature, cash flows can be used to manage earnings by timing reported or actual economic events to shift income between periods to influence the earnings figure reported to external audiences. To investigate whether it is accruals or the timing of real economic events that Chinese firms use to manage earnings, this study analyses the pooled, cross-sectional distribution of reported cash flows from operations across the test period. Panel A of Figure 4 shows the distribution of scaled cash flows. In contrast with the results found for net income after tax in Figure 1, visual inspection appears to show no significant discontinuity at the zero threshold. The test statistic is 2.05 for the interval above zero and -0.65 for the interval below. Although the standardised difference of the interval right of zero is significant at a 5 per cent level, the results of that to the left of zero do not support the hypothesis that there is a discontinuity at the zero threshold for scaled cash flows. Visual inspection of the changes in the scaled cash-flows histogram in Panel B of Table 4 also shows no obvious discontinuity, which is supported by the test statistics of 1.34 above zero ( -1.79 below zero).

Since there are no significant discontinuities at zero in either the distribution of cash flows or the changes in cash flows, the above results suggest that it is accruals rather than the timing of actual cash flows that Chinese firms use to manage earnings.

\section{CONCLUSION}

This study finds evidence of pervasive earnings management to meet regulatory benchmarks among Chinese firms. Specifically, we find evidence that firms manage earnings to avoid the zero threshold due to the implications for their listing status of reporting an initial loss. We also find evidence that firms manage earnings to meet the requirements for rights issues and that the earnings-management behaviour changes as the exogenously determined requirement changes. In addition, and 
in contrast to the findings of Burgstahler and Dichev (1997), the results show no significant discontinuities in reported cash flows from operations (and changes in cash flows from operations), indicating that accruals rather than the timing of real economic events is the method Chinese firms use to manage earnings during the observation period. We find no evidence that firm-size influences the earnings management behaviour of the Chinese firms.

The findings therefore suggest that the CSRC should consider more non-earnings information when making decisions about securities delisting and rights issues. Moreover, investors need to be aware of regulation-related incentives for earnings management when analysing the financial statements of listed Chinese firms; more attention should be paid to the quality and structure of the earnings. In addition, the users of financial statements should consider other non-financial information related to the listed companies other than the earnings itself to 'see through' the managed earnings.

\section{ENDNOTES}

1 Because it is those firms that manage earnings that will fall to the right of an earnings threshold in the histogram, the test statistics quoted in the results section are for the interval immediately above the threshold, with the interval immediately below the threshold shown in brackets. Unless otherwise stated, all significance levels reported in the results section are one-tailed.

\section{REFERENCES}

Aharony, J., Lee J. and Wong, T. (2000). Financial Packaging of IPO Firms in China, Journal of Accounting Research, Vol. 38, No. 1, pp. 103-26.

Ayers, B.C., Jiang, J. and Yeung, P.E. (2006). Discretionary Accruals and Earnings Management: An Analysis of Pseudo Earnings Targets, The Accounting Review, Vol. 81, No. 3, pp. 617-652.

Beaver, W., McNichols, M. and Nelson, K. (2007). An Alternative Interpretation of the Discontinuity in Earnings Distributions, Review of Accounting Studies, Vol. 12, No. 4, pp. 525-566.

Bhattacharya, N., Black, E.L., Christensen, T.E. and Larson, C.R. (2003). Assessing the Relative Informativeness and Permanence of Pro Forma Earnings and GAAP Operating Earnings, Journal of Accounting and Economics, Vol. 36, pp. 285-319.

Burgstahler, D. and Dichev, I. (1997). Earnings Management to Avoid Earnings Decreases and Losses, Journal of Accounting and Economics, Vol. 24, pp. 99-126.

Chen, C.W. and Yuan, H.Q. (2004). Earnings Management and Capital Resource Allocation: Evidence from China's Accounting-Based Regulation of Rights Issues, The Accounting Review, Vol. 79, No. 3, pp. 645-665.

Chen, D., Jian, M. and Xu, M. (2009). Dividends for Tunnelling in a Regulated Economy: The Case of China, Pacific-Basin Finance Journal, Vol. 17, No. 2, pp. 209-223.

Chen, K.C.W. and Schoderbek, M.P. (1999). The Role of Accounting Information in Security Exchange Delisting, Journal of Accounting and Public Policy,Vol. 18, No. 1, pp. 31-57.

Dechow, P.M., Richardson, S.A. and Tuna, A.I. (2003). Why Are Earnings Kinky? An Examination of the Earnings Management Explanation, Review of Accounting Studies, Vol. 8, pp. $355-84$. 
Yang and Mulcahy

Dechow, P.M., Sloan, R.G. and Sweeney, A.P. (1995). Detecting Earnings Management, The Accounting Review, Vol.70, pp. 193-225.

Degeorge, F., Patel, J. and Zeckhauser, R. (1999). Earnings Management to Exceed Thresholds, Journal of Business, Vol. 72, No. 1, pp. 1-33.

Durtschi, C. and Easton, P. (2005). Earnings Management? The Shapes of the Frequency Distributions of Earnings Metrics Are Not Evidence Ipso Facto, Journal of Accounting Research, Vol. 43, No. 4, pp. 557-592.

Hansen, J.C. (2010). The Effect of Alternative Goals on Earnings Management Studies: An Earnings Benchmark Examination, Journal of Accounting and Public Policy, Vol. 29, No. 5, pp. 459-480.

Hayn, C. (1995). The Information Content of Losses, Journal of Accounting and Economics, Vol. 20, pp. 125-153.

Haw, I., Qi, D., Wu, D. and Wu, W. (2005). Market Consequences of Earnings Management in Response to Security Regulations in China, Contemporary Accounting Research, Vol. 22, No. 1, pp. 95-140.

Healy, P. (1985). The Effect of Bonus Schemes on Accounting Decisions, Journal of Accounting and Economics, Vol. 7, pp. 85-107.

Holland, D. and Ramsay, A. (2003). Do Australian Companies Manage Earnings to Meet Simple Earnings Benchmarks?, Accounting and Finance, Vol. 43, pp. 41-632.

Huang, J., Shen, Y. and Sun, Q. (2011). Nonnegotiable Shares, Controlling Shareholders, and Dividend Payments in China, Journal of Corporate Finance, Vol. 17, pp. 122-133.

Jiang, Y.H. (1999). System Guarantee of Anti-Earnings Management, Listed Companies, No. 4.

Jiang, Y.H. and Wei, G. (1998). An Empirical Study of the ROE Distribution of Listed Companies in Collection of Accounting Research on Listed Companies, Shanghai University of Finance and Economics (in Chinese).

Jones, J.J. (1991). Earnings Management During Import Relief Investigations, Journal of Accounting Research, Vol. 29, pp. 193-228.

Kao, J.L., Wu, D. and Yang, Z. (2009). Regulations, Earnings Management, and Post-IPO Performance: the Chinese Evidence, Journal of Banking and Finance, Vol. 33, No. 1, pp. 63-76.

Kim, Y.S., Liu, C.X. and Rhee, S.G. (2003). The Relation of Earnings Management to Firm Size, working paper, University of Hawai'i, USA.

Leuz, C., Nanda, D. and Wysocki, P.D. (2003). Earnings Management and Investor Protection: An International Comparison, Journal of Financial Economics, Vol. 69, pp. 505-527.

Lu, J.Q. (1999). An Empirical Study on the Earnings Management of Loss Listed Companies in China, Accounting Research, Vol. 9, pp. 25-35.

McNichols, M.F. (2000). Research Design Issues in Earnings Management Studies, Journal of Accounting and Public Policy, Vol. 19, pp. 313-345.

Ronen, J. and Yaari, V. (2010). Earnings Management: Emerging Insights in Theory, Practice, and Research, New York, USA: Springer Science + Business Media, LLC.

Sun, Z. and Wang, Y.T. (1999). A Positive Study on Disposing the Resources and Controlling the Surplus, The Study of Finance and Economics, Vol. 4, pp. 3-9.

$\mathrm{Yu}, \mathrm{Q} ., \mathrm{Du}, \mathrm{B}$. and Sun, Q. (2006). Earnings Management at Rights Issues Thresholds - Evidence from China, Journal of Banking and Finance, Vol. 30, pp. 3,453-3,468. 